\title{
OPEN Author Correction: 3D shear wave velocity model of the crust and uppermost mantle beneath the Tyrrhenian basin and margins
}

\author{
D. Manu-Marfo ${ }^{1,2}$, A. Aoudia ${ }^{1}$, S. Pachhai $\mathbb{1}^{1,3,4}$ \& R. Kherchouche ${ }^{1,5,6}$ \\ Correction to: Scientific Reports https://doi.org/10.1038/s41598-019-40510-z, published online 05 March 2019
}

The original version of this Article omitted an affiliation for author Radia Kherchouche. The correct affiliations are listed below.

1- The Abdus Salam International Center for Theoretical Physics, Trieste, Italy;

5- Université des Sciences et de la Technologie Houari Boumediene, Algiers, Algeria;

6- Now at Centre de Recherche en Astronomie, Astrophysique et Géophysique, Algiers, Algeria.

This has now been corrected in the HTML and PDF versions of this Article, and in the accompanying Supplemental Material.

(i) Open Access This article is licensed under a Creative Commons Attribution 4.0 International License, which permits use, sharing, adaptation, distribution and reproduction in any medium or format, as long as you give appropriate credit to the original author(s) and the source, provide a link to the Creative Commons license, and indicate if changes were made. The images or other third party material in this article are included in the article's Creative Commons license, unless indicated otherwise in a credit line to the material. If material is not included in the article's Creative Commons license and your intended use is not permitted by statutory regulation or exceeds the permitted use, you will need to obtain permission directly from the copyright holder. To view a copy of this license, visit http://creativecommons.org/licenses/by/4.0/.

(C) The Author(s) 2019

\footnotetext{
${ }^{1}$ The Abdus Salam International Center for Theoretical Physics, Trieste, Italy. ${ }^{2}$ University of Trieste, Trieste, Italy. ${ }^{3}$ Bullard Laboratories, Department of Earth Sciences, University of Cambridge, Cambridge, UK. ${ }^{4}$ Now at Institute of Geophysics and Planetary Physics, Scripps Institution of Oceanography, University of California, San Diego, California, USA. ${ }^{5}$ Université des Sciences et de la Technologie Houari Boumediene, Algiers, Algeria. ${ }^{6}$ Now at Centre de Recherche en Astronomie, Astrophysique et Géophysique, Algiers, Algeria. Correspondence and requests for materials should be addressed to A.A. (email: aoudia@ictp.it)
} 